\title{
Sylvain Ledda, Alfred de Musset. Les fantaisies d'un enfant du siècle
}

\section{Lise Sabourin}

\section{Q OpenEdition}

10 Journals

\section{Édition électronique}

URL : http://journals.openedition.org/studifrancesi/6361

DOI : 10.4000/studifrancesi.6361

ISSN : 2421-5856

Éditeur

Rosenberg \& Sellier

\section{Édition imprimée}

Date de publication : 1 novembre 2010

Pagination : 572

ISSN : 0039-2944

\section{Référence électronique}

Lise Sabourin, «Sylvain Ledda, Alfred de Musset. Les fantaisies d'un enfant du siècle », Studi Francesi [En ligne], 162 (LIV | III) | 2010, mis en ligne le 30 novembre 2015, consulté le 08 janvier 2021. URL : http:// journals.openedition.org/studifrancesi/6361 ; DOI : https://doi.org/10.4000/studifrancesi.6361

Ce document a été généré automatiquement le 8 janvier 2021.

\section{(c) $(1) \&$}

Studi Francesi è distribuita con Licenza Creative Commons Attribuzione - Non commerciale - Non opere derivate 4.0 Internazionale. 
Sylvain Ledda, Alfred de Musset. Les fantaisies d'un enfant du siècle

\author{
Lise Sabourin
}




\section{RÉFÉRENCE}

SYLVAIN LEDDA, Alfred de Musset. Les fantaisies d'un enfant du siècle, Gallimard, 2010,

«Découvertes», pp. 128.

1 La collection «Découvertes Gallimard» offre au grand public une information scientifique enrichie d'iconographie: il est donc heureux qu'elle ait donné place à Sylvain Ledda pour présenter la destinée de Musset, dans un format plus léger que la grande biographie due à Frank Lestringant (Flammarion, 1999). En effet, l'auteur est un vrai spécialiste du théâtre romantique, particulièrement de celui de «l'enfant du siècle», dont il a publié également romans et contes.

Il nous délivre donc en quatre chapitres («Scènes d'enfant», «Le poète indocile», «Elles et lui», "Splendeurs et misères d'un poète») une vision synthétique et précise à la fois de ses années de jeunesse, de sa gloire poétique, de ses diverses amours et de sa reconnaissance sociale au déclin d'une vie déchirée entre quête d'idéal et excès suicidaires malgré une fantaisie voulue salvatrice.

3 L'illustration est bien choisie, présentée avec élégance et variété (des dessins croqués par Musset à ses lieux de vie, de ses portraits à ses manuscrits et éditions). La dimension scénique n'est pas oubliée (Sylvain Ledda est également comédien et metteur en scène) par des doubles pages confrontant l'évolution des interprétations.

4 Un dossier final sélectionne en anthologie des extraits de ses pièces, notamment les proverbes, de sa correspondance amoureuse, des appréciations critiques - très contrastées on le sait - portées sur sa vie et son œuvre au fil du siècle, enfin propose une brève histoire de sa réception dramatique, une chronologie, une bibliographie et un index des œuvres comme des personnes. 